\title{
Helyi érzéstelenítők antibakteriális hatása
}

\author{
Szabó Zoltán dr. ${ }^{1}$ - Szentkirályi Éva ${ }^{2}$ - Kovács Tamás dr. ${ }^{3}$ \\ Győrffy Örs dr. ${ }^{3}$ - Sütő Balázs dr. ${ }^{1}$ - Bátai István dr. ${ }^{1}$ - Kerényi Monika dr. ${ }^{2}$ \\ ${ }^{1}$ Pécsi Tudományegyetem, Általános Orvostudományi Kar, Klinikai Központ, \\ Aneszteziológiai és Intenzív Terápiás Intézet, Pécs \\ ${ }^{2}$ Pécsi Tudományegyetem, Általános Orvostudományi Kar, Klinikai Központ, Orvosi Mikrobiológiai Intézet, Pécs \\ ${ }^{3}$ Zala Megyei Szent Rafael Kórház, Aneszteziológiai és Intenzív Terápiás Osztály, Zalaegerszeg
}

\begin{abstract}
Gyógyszereink egy részének jelentős, az eredeti alkalmazástól eltérő hatása is van. Ezek felismerése fontos, hogy elkerüljük a nem várt mellékhatásokat, vagy kihasználjuk ezeket a kedvező adottságokat. A helyi érzéstelenítők antibakteriális hatása 1909 óta ismert, de ennek több évtizeden keresztül nem tulajdonítottak jelentőséget. Az 1960-as években figyeltek fel először az álnegatív mikrobiológiai eredmények lehetőségére, helyi érzéstelenítőket használva a mintavételhez. Tanulmányok igazolták, hogy a bronchoszkópiás, seb-, bőr- vagy fül-, orr-, gégészeti bakteriológiai eredmények is érintve lehetnek. A ma is használt gyógyszerek közül a 0,5\%-os bupivakainnak és a 2\%-os lidokainnak van jelentős antibakteriális hatása Gram-pozitív és Gram-negatív baktériumokkal szemben, ami kifejezettebb $37^{\circ} \mathrm{C}$-on, mint szobahőmérsékleten. A legerősebb antibakteriális hatást a $0,5 \%$-os bupivakain mutatta. A napi gyakorlatban alkalmazott koncentrációjuk magasabb, mint a különböző klinikai izolátumokkal szemben meghatározott minimális gátló koncentráció. Fenti tulajdonságaik alapján felmerült szerepük a kórházi sebfertőzések csökkentésében is. A hatásmechanizmus több pontja ismert, károsítják a sejthártya integritását, és több bakteriális enzim múködését gátolják. Orv Hetil. 2021; 162(5): 171-176.
\end{abstract}

Kulcsszavak: helyi érzéstelenítő, antibakteriális, bupivakain, lidokain

\section{Antibacterial effect of local anaesthetics}

Medications may have important impacts other than the original effect. It is important to know about these to avoid side effects or use these beneficial capabilities. The antibacterial effect of local anaesthetics has been known since 1909. For decades, no attention has been payed to this fact. In the 1960s, the high number of negative microbiological results when local anaesthetics were used before sampling drew attention to the possible antibacterial effect. Studies suggested that cultures from bronchoscopy, wound, skin or nasal samples may be affected. Bupivacaine 0,5\% and lidocaine $2 \%$ have the most noticeable effect against both Gram-positive and Gram-negative bacteria. This impact is more pronounced at $37{ }^{\circ} \mathrm{C}$ than at room temperature. Bupivacaine $0,5 \%$ has the most pronounced effect. The concentration of local anaesthetics in daily routine is higher than the minimal inhibitory concentration against various clinical isolates. In the view of these results, they may contribute to reduce surgical site infections. There are known details regarding the mechanism of action. Local anaesthetics have target sites on cellular membrane and inhibit bacterial enzymes.

Keywords: local anaesthetic, antibacterial, bupivacaine, lidocaine

Szabó Z, Szentkirályi É, Kovács T, Győrffy Ö, Sütő B, Bátai I, Kerényi M. [Antibacterial effect of local anaesthetics]. Orv Hetil. 2021; 162(5): 171-176.

(Beérkezett: 2020. július 23.; elfogadva: 2020. augusztus 18.)

\section{Rövidítések}

DNS = dezoxiribonukleinsav; $\mathrm{MIC}=($ minimal inhibitory con centration) minimális gátló koncentráció; MRSA = meticillinrezisztens Staphylococcus aureus; SSI = (surgical site infection) mütétet követő sebfertőzés
Helyi érzéstelenítőket több mint 100 éve használunk mútéti érzéstelenítéshez és a posztoperatív fájdalom, stresszválasz csökkentéséhez. Az első szert, a kokaint először szemészeti beavatkozáshoz használták 1884-ben 
[1]. A regionális anesztézia kifejezés az idegsebész Harvey Cushingtól származik 1900-ból [2].

A helyi érzéstelenítők antibakteriális hatásáról az első adat 1909-ból származik. Jonnesco a regionális anesztéziáról írt közleményében állítja: a sztovaint, a tropakokaint és a novokaint intrathecalis (spinalis) érzéstelenítéshez nem kell sterilezni, mert önmagukban antiszeptikusak. Sajnos állításáról nem közölt részleteket, nem támasztotta alá referenciával [3].

Több évtizednyi szünet után, 1955-ben szemészek vizsgálták helyi érzéstelenítőjüket, a tetrakaint, nem okoznak-e fertőzést a kontaminált gyógyszerrel. A tetrakainnak önmagában nem volt hatása, de tartósítószerrel kombinálva Pseudomonas-ellenes hatását figyelték meg [4]. Pár évvel később (1961) a tüdőgyógyászok egészen más aggályok miatt vizsgálták a helyi érzéstelenítők antimikrobás hatását. Feltűnt, hogy érzéstelenítőket használva a légutak mikrobiológiai mintavételéhez, sok a negatív eredmény [5].

A további vizsgálatokhoz a kórházi infekciók csökkentésének célja vezetett. A mütétet követő sebfertőzések (SSI-k) gyakorisága 2\% és $8 \%$ között változik, ami jelentôsen emeli a morbiditást, a mortalitást és a költségeket [6]. A kórházi fertőzésekhez hozzájárulhat az elkészítése során kontaminált gyógyszer is. Gyógyszereink kontaminációja felszívásuk, beadásuk során a 23\%-ot is elérheti $[7,8]$. Az üvegampullák kinyitásakor üvegrészecskék kerülnek a folyadékba. Ha nem tartjuk be maradéktalanul a higiéniás elő́rásokat, az üvegrészecskékkel baktériumok is kerülnek az oldatba [9]. Azok a gyógyszerek, amelyek támogatják a baktériumok növekedését, súlyos kórházi fertőzést okozhatnak [10], míg az antibakteriális hatásúakban elpusztulnak a kontaminált csírák [8, 11, 12].

$\mathrm{Az}$ intrathecalis (spinalis) és epiduralis érzéstelenítési technikák jelentős térhódítása is további kutatásokra sarkallt. Az epiduralis kanülök jelentőségét külön kiemeli, hogy a posztoperatív szakban napokig, de tartós fájdalomcsillapításra hetekig, hónapokig használjuk azokat.

\section{Általános jellemzők}

A helyi érzéstelenítők antibakteriális hatása koncentráció- és hőmérsékletfüggő. Szobahőmérsékleten kevésbé kifejezett, mint $37{ }^{\circ} \mathrm{C}$-on [13]. Escherichia coli, Pseudomonas aeruginosa, Staphylococcus aureus, Streptococcus pneumoniae, Streptococcus pyogenes, Enterococcus faecalis, Bacillus cereus, Candida albicans növekedését vizsgálták bupivakainban, melynek $0,5 \%$-os oldata a $P$. aeruginosa kivételével az összes törzs növekedését, a 0,25 \%-os csak a Staphylococcus és Streptococcus törzseket gátolta, míg a $0,125 \%$-os nem mutatott antibakteriális hatást [14].

A különböző gyógyszerek hatáserősségének összehasonlítását több szerző is elvégezte. A minimális gátló koncentrációk (MIC-ek) meghatározása alapján Grampozitív és -negatív törzsekkel szemben is az ametokain volt a leghatásosabb, ezt követte a bupivakain, a prilokain, és a lidokain [15]. Több szerző megerősítette, hogy a baktériumok szaporodását a ma is használt szerek közül a bupivakain 0,5\%-os oldata gátolta a leghatásosabban, ezt követte a bupivakain 0,25\%-os, majd a lidokain $2 \%$-os oldata [16].

Kórházban fekvő betegekből származó Haemophilus influenzae izolátumain vizsgálva a lidokain hatását azt tapasztalták, hogy egy fajon belül is jelentős különbség lehet a MIC-értékekben, amelyek ebben a vizsgálatban 0,6 és $5 \mathrm{mg} / \mathrm{ml}$ között változtak [17].

Helyi érzéstelenítéshez lidokaint önmagában vagy adrenalinnal együtt is használhatunk. Ezt a két gyógyszert alkalmazták először egy összehasonlító vizsgálatban: a lidokaint 2\%-os oldatban, az adrenalint 1 : 100000 arányú hígításban. Az eredmények szerint az adrenalinmentes lidokain hatása szignifikánsan erősebb volt [18]. Egy újabb vizsgálat az előbbivel ellentétes hatást talált: az adrenalinos oldat (az adrenalin mennyiségét nem adták meg) bizonyult jelentősebb antibakteriális hatásúnak [19].

A fenti példák eredményei felhívják a figyelmet a standardizált módszerek hiányára és az ebből származó, nehezen összehasonlítható eredményekre. A két kísérlet különböző törzseket használt, eltérő volt a kiindulási csíraszám, a behatási idő és a hőmérséklet, még az adrenalin mennyiségét se adta meg az újabb közlemény.

További vizsgálatok szükségesek annak eldöntésére is, hogy a helyi érzéstelenítők szubinhibitoros koncentrációja az antibiotikumokhoz hasonlóan befolyásolja-e a kórokozók adherenciáját, ami az infekció kialakulásának meghatározó lépése $[20,21]$.

\section{Helyi érzéstelenítők hatása a mikrobiológiai mintavétel eredményére}

Először a tüdőgyógyászok gondoltak arra, hogy a mikrobiológiai mintavételezéshez használt helyi érzéstelenítők álnegatív eredményt adhatnak. Helyi érzéstelenítőt használva a bronchoszkóppal végzett mikrobiológiai mintavételezéshez, feltűnt, hogy gyakoribb a negatív mikrobiológiai tenyésztési lelet, mint az a nélkül vett minták esetén. A tüdőtükrözéshez használt helyi érzéstelenítőknek a baktériumok növekedését befolyásoló hatását 1961-ben vizsgálták. Ekkor klórbutanol-tartalmú tetrakaint vagy metil-parabént tartalmazó lidokaint használtak a légutak vizsgálatának elviselhetőbbé tételére. A tetrakain $0,5 \%$-os oldata gátolta a $S$. aureus és a $C$. albicans növekedését (a bronchoszkópiához 1\%-osat alkalmaztak) [5]. A mintavételhez 2\%-os lidokaint használva nem tudták a Mycobacterium tuberculosist kitenyészteni 10 olyan betegből, akiknél gyógyszeres előkészítés nélkül korábban pozitív tenyésztési eredményeket kaptak a mintáikból [22]. Az újabb tanulmányok megerősítették a helyi érzéstelenítők antibakteriális hatását. Már nemcsak a tüdőgyógyászok, de a szemészek is megállapították és hangsúlyozták, hogy helyi érzéstelenítő használata után a negatív bakteriológiai lelet álnegatív lehet [23]. 
A kilinikumhoz hasonló viszonyokat vizsgáltak Olsen és mtsai. Bronchoalveolaris mosófolyadékokba lidokaint tettek, és azt különböző klinikai mintákból izolált $S$. pneumoniae, H. influenzae, P. aeruginosa és C. albicans törzsekkel kontaminálták. A behatási idő 1 óra volt, amenynyi idő legalább kell a levett minta mikrobiológiai laborba jutásához. Tanulmányukban a fenti kórokozók közül egyedül a $S$. pneumoniae csíraszáma csökkent olyan mértékben, hogy az esetleges légúti mintavétel eredménye nem tükrözi a valós fertőzést [24].

A fül-, orr-, gégészeti (orrüregi) mintavételek előtt gyakran alkalmaznak 4\%-os lidokaint fenilefrinnel vagy 4\%-os kokaint. Mindkét helyi érzéstelenítő antibakteriális volt a vizsgált orr- és melléküregi fertőzéseket okozó Branbamella catarrhalis, Enterobacter sp., H. influenzae, Klebsiella pneumoniae, $P$. aeruginosa, S. aureus és $S$. pneumoniae törzsekkel szemben [25].

A bőr és a sebek érzéstelenítéséhez használt EMLA krém (lidokain: 2,5\% és prilokain: 2,5\%) baktericid 1 órán belül E. coli, P. aeruginosa, 2 órán belül Micrococcus spp. és 4 órán belül $S$. aureus és meticillinrezisztens S. aureus (MRSA) törzsekkel szemben [26]. Az EMLA krémnek a fájdalmas mintavételek előtti alkalmazása is meghamisíthatja a mikrobiológiai eredményeket. Antibakteriális hatása kifejezettebb, mint az alkoholtartalmú kézfertőtlenítő szeré [27].

\section{Helyi érzéstelenítők hatása a regionális érzéstelenítési technikák fertózéses szövődményeire}

A regionális érzéstelenítés (intrathecalis, epiduralis) fertőzéses szövődményei ritkák. Becsült incidenciáját 1 : 1930 [28] és 1 : 40000 között adták meg [29]. Ezt részben a jól kidolgozott steril technikáknak, a tiszta környezetnek, részben pedig az itt alkalmazott helyi érzéstelenítők antibakteriális hatásának tudták be.

A bupivakain antibakteriális hatását először 1976-ban vizsgálták. Staphylococcus epidermidis klinikai izolátumait tanulmányozták $37^{\circ} \mathrm{C}$-on és szobahőmérsékleten bupivakain $0,25 \%$-os oldatában. $37{ }^{\circ} \mathrm{C}$-on ez a híg forma is baktericid volt az összes törzzsel szemben, míg szobahőmérsékleten az izolátumok felénél emelkedett a csíraszám az első 3 órában, majd lecsökkent [30]. Tíz évvel később 10 laboratóriumi referenciatörzs és klinikai izolátum (E. coli, P. aeruginosa, S. aureus, S. pneumoniae, $S$. pyogenes, E. faecalis, B. cereus, C. albicans) növekedését vizsgálták bupivakain 0,05-0,5\%-os hígításában. A $0,5 \%$-os oldat a $P$. aeruginosa kivételével az összes törzs növekedését gátolta; a $0,25 \%$-os csak a Staphylococcus és Streptococcus törzseket gátolta, míg a 0,125\%-os nem mutatott antibakteriális hatást [14]. A 0,5\%-os bupivakain és a 2\%-os lidokain antibakteriális hatását a fentieken kívül is több tanulmány bizonyította [15].

A ropivakain $10 \mathrm{mg} / \mathrm{ml}$-es oldata csökkentette a $S$. aureus és $E$. coli csíraszámát szobahőmérsékleten és
$37{ }^{\circ} \mathrm{C}$-on, míg a $2 \mathrm{mg} / \mathrm{ml}$-ben csak a $S$. aureus csíraszáma csökkent, az E. coli 3 óra után jelentős növekedést mutatott [31]. Más szerzők ropivakain $5 \mathrm{mg} / \mathrm{ml}$ és hígabb oldatait vizsgálva nem találtak antibakteriális hatást [32].

Az antibakteriális hatás a koncentráció csökkenésével gyorsan gyengül, majd megszűnik. A koncentráció tartósan, epiduralisan adva alacsonyabb lehet, mint a MICek, de intrathecalisan is jelentős hígulás következik be. Ezért egyes szerzők kétségbe vonják, hogy a helyi érzéstelenítők befolyásolják-e a gerincközeli gennyedések kialakulását [33]. A fenti feltételezést támasztotta alá a bupivakain MIC-értékeinek meghatározása: S. pneumoniae, $S$. pyogenes, $S$. epidermidis és $E$. coli esetében 2,5 $\mathrm{mg} / \mathrm{ml}, S$. aureus, MRSA, E. faecalis törzseknél $5 \mathrm{mg} /$ $\mathrm{ml}, P$. aeruginosa és $C$. albicans esetében $5 \mathrm{mg} / \mathrm{ml}$-nél nagyobb volt [34].

Amit valószínúsíthetünk és megállapíthatunk: ha az intrathecalisan, epiduralisan adott lidokain 2\%-os, bupivakain $0,5 \%$-os oldata kontaminálódik az elkészítés során, az ampullákban a kórokozók nagy része nem indul növekedésnek (kivétel: P. aeruginosa és C. albicans), de az epiduralis térbe más úton bejutó kórokozóktól nem védenek.

\section{Helyi érzéstelenítők hatása a sebfertőzésekre}

A SSI a harmadik leggyakoribb nosocomialis infekció, ezért megelőzésének, csökkentésének nagy jelentősége van [35-37].

$\mathrm{Az}$ in vitro vizsgálatok alapján merült fel a kérdés, nyújthat-e védelmet a SSI-kkel szemben a helyi érzéstelenítők használata. Az állatkísérletek eredményei nem egyértelmúek, amit magyarázhat a több fajt érintő SSImodellek megléte, illetve az egy fajon belül is használt több SSI-lehetőség.

Amikor állatkísérlet során $S$. aureusszal kontaminálták a tengerimalacon ejtett sebet, jelentős csíraszámcsökkenést tapasztaltak, ha a sebet elötte $2 \%$-os lidokainnal infiltrálták. Ugyanakkor az adrenalinnal (1 : 100 000) kombinált lidokain a hússzorosára emelte a csíraszámot [38]. Ez egybevág azzal az in vitro vizsgálattal, amelynél lidokainban nem növekedtek a baktériumok, de lidokain és adrenalin keverékében igen [18]. Egérmodellben, folyamatos 2\%-os lidokaininfúziót alkalmazva a sebvonalban, szignifikáns csíraszám-redukciót találtak $S$. aureus okozta sebfertőzésben [39].

A helyi érzéstelenítőknek a SSI-csökkentésre való hatástalanságára is találunk állatkísérletes példát. Patkánymodellben a prilokain, a bupivakain és az artikain nem mutatott védőhatást a $S$. aureus okozta sebfertőzés kialakulására [40]. Egérmodellben nem mutatkozott különbség lidokain- vagy bupivakaininfiltrációt követő $S$. aureus vagy E. coli kontamináció utáni sebfertőzés kialakulásában a kontrollhoz képest. Ebben a kísérletben is az in vitro vizsgálatok alapján kevésbé hatásosnak mutatko- 
zó 1\%-os lidokaint és 0,25\%-os bupivakaint használták [41].

A humántanulmányok közül egy prospektív, randomizált vizsgálat a lidokain hatását nézte. Sebzárás előtt 2\%os lidokaint használva lokálisan, a SSI előfordulása a kontroll 28\%-ról 9\%-ra csökkent a megfigyelt 30 napos időszakban $(\mathrm{p}<0,02)$. A leggyakoribb kórokozó az $E$. coli volt [42].

Nagy hasi (máj, pancreas) mütétet követően peritonealisan, folyamatos infúzióban adott $0,2 \%$-os ropivakain nem befolyásolta a SSI gyakoriságát [43]. Korábbi in vitro munka már bizonyította, hogy a $0,2 \%$-os ropivakainnak korlátozott antibakteriális hatása lehet, de az E. coli csíraszáma 3 óra után emelkedik benne [31]. Regionális anesztéziában végzett térd- és csípőprotézis-mütét [44] vagy császármetszés után szignifikánsan kevesebb a SSI, mint általános narkózist követően [45]. Az okokat nem a helyi érzéstelenítők direkt antibakteriális hatásában vélték felfedezni, hanem a regionális anesztéziának a szimpatikus tónus csökkenésével járó, jobb perfúziót és szöveti oxigenizációt eredményezô, valamint az immunrendszert kevésbé deprimáló hatását emelték ki.

$\mathrm{Az}$ epiduralisan adott lidokainnak egy lehetséges új, SSI-t csökkentő hatásmechanizmusáról is beszámoltak. A lipokalin-2 (neutrofil zselatinázasszociált fehérje) a neutrofileken, vese-, prosztatasejteken és az epitheliumon fejeződik ki, és gátló hatású a baktériumok növekedésére a vasfelvevő képességük korlátozásával [46]. A fenti feltevést állatkísérlettel is igazolták. Patkánykísérlet során bőrmetszést E. colival fertőztek. Az epiduralisan lidokaint kapott csoportban a lipokalin-2 szérum- és szöveti szintjének emelkedését, valamint a sebben csökkent E. coli DNS-t mutattak ki [47].

Korábban leírták, hogy a lidokain és a prilokain gátolhatja az emberi fibroblastok, endothelsejtek és keratinocyták proliferációját in vitro. A legújabb tanulmány szerint a lidokain felületi alkalmazása egyértelmúen javította a sebgyógyulást [48].

A fogászati, szájsebészeti beavatkozások kapcsán adott helyi érzéstelenítésről feltételezték, hogy véráramfertőzést okozhat az érpályába injektálva a szájüregben található baktériumokat, és a helyi szövetsérülés miatt. Artikain, bupivakain, mepivakain, prilokain, lidokain, butanilikain és prokain hatását nézték szájüregben taláható, a normálflórához tartozó és patogén baktériumokra. A vizsgált törzsek esetében a MIC és a minimális baktericid koncentráció is alacsonyabb volt, mint a vezetéses érzéstelenítéshez adott helyi érzéstelenítő koncentrációja [49]. A szájüregben is használt 10\%-os lidokainspray hatását in vitro vizsgálták E. coli, E. faecalis, S. aureus, Streptococcus salivarius, S. pyogenes és Streptococcus sanguinis klinikai izolátumain. Az eredmények antibakteriális hatást igazoltak az E. coli, a $S$. sanguinis és a $S$. salivarius esetében [50].

A fogászati, szájsebészeti beavatkozások kapcsán, a baktériumokkal borított nyálkahártya ellenére ritkán látható helyi fertőzéseket a fentiekkel is magyarázzák.

\section{Hatásmechanizmus}

A helyi érzéstelenítők antibakteriális hatásmechanizmusát először 1979-ben vizsgálták. Tetrakain és prokain hatására mikromorfológiai eltéréseket, káliumkiáramlást, enzimaktivitás-csökkenést (szukcinát-dehidrogenáz) találtak Bacillus törzseknél [51]. Az ametokain, a prokain, a cinchokain és a lidokain befolyásolta $E$. colinál a membránok integritását, és sejtalkotók távoztak a baktériumból. Elektronmikroszkóppal vizsgálva filamentumok jelentek meg a helyi érzéstelenítőnek kitett baktériumokon [52]. Más tanulmányok is kimutatták, hogy a helyi érzéstelenítők gátolják a bakteriális DNS- és fehérjeszintézist [53], enzimaktivitást (alkán-hidroxiláz), és károsítják a sejtmembránfunkciót [54].

A helyi érzéstelenítők indirekt módon a szöveti lipokalin-2-szint emelésével is kifejtenek antibakteriális hatást $[46,47]$.

\section{Következtetés}

A helyi érzéstelenítők antibakteriális hatása több mint száz éve ismert. Az aneszteziológiában és intenzív terápiában használt több más gyógyszerról is igazolódott az eredeti alkalmazástól eltérő hatás, ami kedvezően befolyásolhatja a posztoperatív infekció kialakulását [11, 5558].

Helyi érzéstelenítőink egyrészt károsan befolyásolhatják a bakteriológiai mintavétel eredményét, elpusztítva a kórokozókat, másrészt segíthetnek a kórházi fertőzések egy részének elkerülésében, ha elpusztítják a gyógyszereinket kontamináló baktériumokat. Humán és állatkísérletes adatok alapján feltételezhetjük, hogy kedvezően hatnak a sebfertőzésekre is.

A helyi érzéstelenítők pontos antibakteriális hatásmechanizmusa nem tisztázott. A kísérletek szerint hatásukat a sejtmembránok integritásának károsításán és fehérjeszintézis-gátláson keresztül is kifejtik.

Anyagi támogatás: A közlemény megírása anyagi támogatásban nem részesült.

Szerzői munkamegosztás: A kézirat megírásához szükséges irodalomkutatásban, illetve a kézirat elkészítésében az összes szerző részt vett. A cikk végleges változatát valamennyi szerző elolvasta és jóváhagyta.

Érdekeltségek: A szerzőknek nincsenek érdekeltségeik.

\section{Irodalom}

[1] Koller C. On the use of cocaine for producing anaesthesia on the eye. Lancet 1884; 124(2): 990-992.

[2] Molnár C, Nemes C, Szabó S, et al. Harvey Cushing, a pioneer of neuroanesthesia. J Anesth. 2008; 22: 483-486.

[3] Jonnesco T. Remarks on general spinal analgesia. Br Med J. 1909; 2: 1396-1401 
[4] Murphy JT, Allen HF, Mangiaracine AB. Preparation, sterilization, and preservation of ophthalmic solutions; experimental studies and a practical method. AMA Arch Ophthalmol. 1955; 53: 63-78.

[5] Erlich H. Bacteriologic studies and effects of anesthetic solutions on bronchial secretions during bronchoscopy. Am Rev Respir Dis. 1961; 84: 414-421.

[6] Waltz PK, Zuckerbraun BS. Surgical site infections and associated operative characteristics. Surg Infect (Larchmt). 2017; 18: 447-450.

[7] Heid F, Bender C, Gervais H, et al. Microbial contamination of anesthetic syringes in relation to different handling habits. Am J Infect Control 2016; 44: el5-el7.

[8] Kerényi M, Borza Z, Csontos C, et al. Impact of medications on bacterial growth in syringes. J Hosp Infect. 2011; 79: 265-266.

[9] Joo GE, Sohng KY, Park MY. The effect of different methods of intravenous injection on glass particle contamination from ampules. SpringerPlus 2016; 5: 15 .

[10] Centers for Disease Control (CDC). Postsurgical infections associated with an extrinsically contaminated intravenous anesthetic agent - California, Illinois, Maine, and Michigan, 1990. MMWR Morb Mortal Wkly Rep. 1990; 39: 426-427, 433.

[11] Bátai I, Kerényi M, Tekeres $M$. The growth of bacteria in intravenous glyceryl trinitrate and in sodium nitroprusside. Anesth Analg. 1999; 89: 1570-1572.

[12] Ittzés B, Weiling Z, Bátai IZ, et al. Atropine and glycopyrrolate do not support bacterial growth-safety and economic considerations. J Clin Anest. 2016; 35: 560-563.

[13] Taki Y, Seki K, Ikigai H, et al. Effect of temperature on antibacterial activity of lidocaine to Staphylococcus aureus and Pseudomonas aeruginosa. Microbiol Immunol. 1988; 32: 429-434.

[14] Rosenberg PH, Renkonen OV. Antimicrobial activity of bupivacaine and morphine. Anesthesiology 1985; 62: 178-179.

[15] Zaidi S, Healy TE. A comparison of the antibacterial properties of six local analgesic agents. Anaesthesia 1977; 32: 69-70.

[16] Sakuragi T, Ishino H, Dan K. Bactericidal activity of clinically used local anesthetics on Staphylococcus aureus. Reg Anesth. 1996; 21: 239-242.

[17] Ravin CE, Latimer JM, Matsen JM. In vitro effects of lidocaine on anaerobic respiratory pathogens and strains of Haemophilus influenzae. Chest 1977; 72: 439-441.

[18] Sculley PD, Dunley RE. Antimicrobial activity of a lidocaine preparation. Anesth Prog. 1980; 27: 21-23.

[19] Kesici U, Demirci M, Kesici S. Antimicrobial effects of local anaesthetics. Int Wound J. 2019; 16: 1029-1033.

[20] Yuksel FN, Karatug NT, Akcelik M. Does subinhibitory concentrations of clinically important antibiotic induce biofilm production of Enterococcus faecium strains? Acta Microbiol Immuno Hung. 2018; 65: 27-38.

[21] Šmitran A, Vuković D, Opavski N, et al. Influence of subinhibitory antibiotic concentration on Streptococcus pyogenes adherence and biofilm production. Acta Microbiol Immunol Hung. 2018; 65: 229-240.

[22] Conte BA, Laforet EG. The role of the topical anesthetic agent in modifying bacteriologic data obtained by bronchoscopy. N Engl J Med. 1962; 267: 957-960.

[23] Kleinfeld J, Ellis PP. Inhibition of microorganisms by topical anesthetics. Appl Microbiol. 1967; 15: 1296-1298

[24] Olsen KM, Peddicord TE, Campbell GD, et al. Antimicrobial effects of lidocaine in bronchoalveolar lavage fluid. J Antimicrob Chemother. 2000; 45: 217-219.

[25] Aldous WK, Jensen R, Sieck BM. Cocaine and lidocaine with phenylephrine as topical anesthetics: antimicrobial activity against common nasal pathogens. Ear Nose Throat J. 1998; 77: 554-557.

[26] Kerényi M, Bátai R, Juhász V, et al. Lidocaine/prilocaine cream (EMLA) has an antibacterial effect in vitro. J Hosp Infect. 2004; 56: 75-76.
[27] Bátai I, Bogár L, Juhász V, et al. A comparison of the antimicrobial property of lidocaine/prilocaine cream (EMLA) and an alcohol-based disinfectant on intact human skin flora. Anesth Analg. 2009; 108: 666-668.

[28] Wang LP, Hauerberg J, Schmidt JF. Incidence of spinal epidural abscess after epidural analgesia: a national 1-year survey. Anesthesiology 1999; 91: 1928-1936.

[29] Moen V, Dahlgren N, Irestedt L. Severe neurological complications after central neuraxial blockades in Sweden 1990-1999. Anesthesiology 2004; 101: 950-959.

[30] James FM, George RH, Naiem H, et al. Bacteriologic aspects of epidural analgesia. Anesth Analg. 1976; 55: 187-190.

[31] Bátai I, Kerényi M, Falvai J, et al. Bacterial growth in ropivacaine hydrochloride. Anesth Analg. 2002; 94: 729-731.

[32] Aydin ON, Eyigor M, Aydin N. Antimicrobial activity of ropivacaine and other local anaesthetics. Eur J Anaesthesiol. 2001; 18 : 687-694.

[33] Feldman JM, Chapin-Robertson K, Turner J. Do agents used for epidural analgesia have antimicrobial properties? Reg Anesth. 1994; 19: 43-47.

[34] Grimmond TR, Brownridge P. Antimicrobial activity of bupivacaine and pethidine. Anaesth Intensive Care 1986; 14: 418420 .

[35] de Lissovoy G, Fraeman K, Hutchins V, et al. Surgical site infection: incidence and impact on hospital utilization and treatment costs. Am J Infect Control 2009; 37: 387-397.

[36] Djuric O, Markovic-Denic L, Jovanovic B, et al. High incidence of multiresistant bacterial isolates from bloodstream infections in trauma emergency department and intensive care unit in Serbia. Acta Microbiol Immunol Hung. 2019; 66: 307-325.

[37] Dimitrov E, Enchev E, Halacheva K, et al. Neutrophil CD64 - a potential biomarker in patients with complicated intra-abdominal infections? A literature review. Acta Microbiol Immunol Hung. 2018; 65: 245-254.

[38] Stratford AF, Zoutman DE, Davidson JS. Effect of lidocaine and epinephrine on Staphylococcus aureus in a guinea pig model of surgical wound infection. Plast Reconstr Surg. 2002; 110: 12751279 .

[39] Lu CW, Lin TY, Shieh JS, et al. Antimicrobial effect of continuous lidocaine infusion in a Staphylococcus aureus-induced wound infection in a mouse model. Ann Plast Surg. 2014; 73: 598-601.

[40] Kose AA, Karabaggli Y, Kiremitci A, et al. Do local anesthetics have antibacterial effect on Staphylococcus aureus under in vivo conditions? An experimental study. Dermatol Surg. 2010; 36: 848-852.

[41] Sams VG, Lawson CM, Coan P, et al. Effect of local anesthetic on microorganisms in a murine model of surgical site infection. J Trauma Acute Care Surg. 2012; 73: 441-446.

[42] Quiroga-Garza A, Valdivia-Balderas JM, Trejo-Sánchez MÁ, et al. A prospective, randomized, controlled clinical trial to assess use of $2 \%$ lidocaine irrigation to prevent abdominal surgical site infection. Ostomy Wound Manage. 2017; 63: 12-21.

[43] Claroni C, Marcelli ME, Sofra MC, et al. Preperitoneal continuous infusion of local anesthetics: what is the impact on surgical wound infections in humans? Pain Med. 2016; 17: 582-589.

[44] Chang CC, Lin HC, Lin HW, et al. Anesthetic management and surgical site infections in total hip or knee replacement: a population-based study. Anesthesiology 2010; 113: 279-284.

[45] Tsai PS, Hsu CS, Fan YC, et al. General anaesthesia is associated with increased risk of surgical site infection after Caesarean delivery compared with neuraxial anaesthesia: a population-based study. Br J Anaesth. 2011; 107: 757-761.

[46] Flo TH, Smith KD, Sato S, et al. Lipocalin 2 mediates an innate immune response to bacterial infection by sequestrating iron. Nature 2004; 432: 917-921.

[47] Igarashi T, Suzuki T, Mori K, et al. The effects of epidural anesthesia on growth of Escherichia coli at pseudosurgical site: the 
roles of the lipocalin-2 pathway. Anesth Analg. 2015; 121: 8189.

[48] Wu SG, Li HT, Wang LL, et al. Lidocaine promotes fibroblast proliferation after thermal injury via up-regulating the expression of miR-663 and miR-486. Kaohsiung J Med Sci. 2020; 36: 274-280.

[49] Pelz K, Wiedmann-Al-Ahmad M, Bogdan C, et al. Analysis of the antimicrobial activity of local anaesthetics used for dental analgesia. J Med Microbiol. 2008; 57: 88-94.

[50] Srisatjaluk RL, Klongnoi B, Wongsirichat N. Antimicrobial effect of topical local anesthetic spray on oral microflora. J Dent Anesth Pain Med. 2016; 16: 17-24.

[51] Silva MT, Sousa JC, Polónia JJ, et al. Effects of local anesthetics on bacterial cells. J Bacteriol. 1979; 137: 461-468.

[52] Fazly Bazas BS, Salt WG. Local anaesthetics as antimicrobial agents: structure-action considerations. Microbios 1983; 37: $45-64$.

[53] Schmidt RM, Rosenkranz HS. Antimicrobial activity of local anesthetics: lidocaine and procaine. J Infect Dis. 1970; 121 : 597607.
[54] Raina JL. Local anesthetics block transient expression of inducible functions for transformation in Streptococcus sanguis. J Bacteriol. 1983; 156: 450-454.

[55] Szabadfi K, Dányádi B, Kiss P, et al. Preconditioning with volatile anaesthetic sevoflurane in ischemic retinal lesion in rats. J Mol Histol. 2012; 43: 565-569.

[56] Batai I, Kerenyi M. Halothane decreases bacterial adherence in vitro. Acta Anaesthesiol Scand. 1999; 43: 760-763.

[57] Csontos C, Rézmán B, Földi V, et al. Effect of N-acetylcysteine treatment on the expression of leukocyte surface markers after burn injury. Burns 2011; 37: 453-464.

[58] Ittzés B, Szentkirályi E, Szabó Z, et al. Amiodarone that has antibacterial effect against human pathogens may represent a novel catheter lock. Acta Microbiol Immunol Hung. 2020; 67: 133137.

(Bátai István dr., Pécs, Ifjúság útja 13., 7623 e-mail: ibatai@gmail.com)

\section{"Utilius ferrum est in sulco quam orichalcum est in proelio." (Hasznosabb a vas a barázdában, mint a réz a harcban.)}

A cikk a Creative Commons Attribution 4.0 International License (https://creativecommons.org/licenses/by/4.0/) feltételei szerint publikált Open Access közlemény, melynek szellemében a cikk bármilyen médiumban szabadon felhasználható, megosztható és újraközölhető, feltéve, hogy az eredeti szerzỏ és a közlés helye, illetve a CC License linkje és az esetlegesen végrehajtott módosítások feltüntetésre kerülnek. (SID_1) 